\title{
Effects of Touching Sculptures on the Artistic Appreciation of Collative Emotional/Perceptual Properties
}

\author{
José Lino Oliveira Bueno ${ }^{1}$ \\ Márcia Regina Motta \\ Vitor Tumas ${ }^{1}$
}

\begin{abstract}
The relationship between physical stimulus and perception is fundamental to understand aesthetic appreciation. This study aimed to examine how the properties of sculptures influence their artistic appreciation. Thirteen participants touched altered sculptures from the series Bichos de Lygia Clark. Participants indicated their perceptions for each stimulus using Semantic Differential Scales (7-point Likert scale): Complexity, Irregularity, Amount of pieces, Interest and Pleasingness. The duration of manipulation was recorded. The results showed that sculptures perceived as having more pieces were the ones judged to have a high level of Complexity and Irregularity. Sculptures evaluated as demonstrating a high level of Complexity and Irregularity were considered more interesting, although less pleasant. Participants tended to spend more time exploring the more complex sculptures. The results indicate that the amount of informational content, represented by the amount of pieces present in the sculpture, can influence the way it is perceived and affect its hedonic value.
\end{abstract}

Keywords: aesthetics, art, sculpturing, exploratory behavior, perception

\section{Efeitos do Toque em Esculturas sobre a Apreciação Artística de Propriedades Colativas Emocionais/Perceptivas}

\begin{abstract}
Resumo: A relação entre estímulo físico e percepção é fundamental para entender a apreciação estética. Este estudo teve como objetivo examinar como propriedades de esculturas influenciam suas apreciações artísticas. Treze participantes tocaram esculturas alteradas da série Bichos de Lygia Clark. Os participantes indicaram suas percepções para cada estímulo usando Escalas de Diferencial Semântico (tipo Likert - 7 pontos): Complexidade, Irregularidade, Quantidade de peças, Interesse e Agradabilidade. A duração da manipulação foi registrada. Os resultados mostraram que esculturas julgadas como tendo maior quantidade de peças foram julgadas como tendo alto nível de Complexidade e Irregularidade. Esculturas avaliadas como demonstrando um alto nível de Complexidade e Irregularidade foram consideradas mais interessantes, embora menos agradáveis. Os participantes tenderam a gastar mais tempo explorando as esculturas mais complexas. Os resultados indicam que a quantidade de conteúdo informacional, representado pela quantidade de peças presente na escultura, pode influenciar o modo como ela é percebida e afetar seu valor hedônico.
\end{abstract}

Palavras-chave: estética, arte, escultura, comportamento exploratório, percepção

\section{Efectos del Toque en Esculturas en relación a la Apreciación Artística de las Propiedades Colativas Emocionales/Perceptivas}

\begin{abstract}
Resumen: La relación entre el estímulo físico y la percepción es esencial para comprender la apreciación estética. Este estudio tuvo como objetivo examinar cómo las propiedades de las esculturas influyen en su apreciación artística. Trece participantes tocaron esculturas alteradas de la serie Bichos de Lygia Clark. Los participantes manifestaron sus percepciones para cada estímulo utilizando Escalas de Diferencial Semántico (de tipo Likert - 7 puntos): Complejidad, Irregularidad, Cantidad de piezas, Interés y Satisfacción. Se registró la duración de la manipulación. Los resultados apuntaron que las esculturas consideradas con más cantidad de piezas tenían un alto grado de Complejidad e Irregularidad. Las esculturas evaluadas con un alto grado de Complejidad e Irregularidad se consideraron más interesantes, aunque menos agradables. Los participantes tendían a pasar más tiempo explorando las esculturas más complejas. Los resultados indican que la cantidad de contenido informativo, representado por la cantidad de piezas presentes en la escultura, puede influir en la forma de percibirla y afectar su valor hedónico.
\end{abstract}

Palabras clave: estética, arte, escultura, comportamiento exploratorio, percepción

'Universidade de São Paulo, Ribeirão Preto-SP, Brazil

Correspondence address: José Lino Oliveira Bueno. Universidade de São Paulo. Departamento de Psicologia. Av. Bandeirantes, 3900, Ribeirão Preto-SP, Brazil. CEP 14.010-080. E-mail: jldobuen@ffclrp.usp.br
The relationship between physical stimulus and perceptual response has been modeled as a dynamic process involving multiple stages of perceptual, cognitive and emotional processing, and they interact together 
(Leder, Belke, Oeberst, \& Augustin, 2004; Tinio, 2013). In the field of artistic appreciation it is fundamental to identify how the features of a piece of art affect perceptual (Bueno e Ramos, 2007) cognitive (Aksentijevic \& Gibson, 2012) and emotional (Calvo, Gutiérrez-Garcia, \& Del Líbano, 2015; Crozier, 2018; Cupchik, Leonard, Axelrad, \& Kalin, 1998) mechanisms during contact with the artistic object.

An influential framework in the field of aesthetic experience and aesthetic judgment was developed by Berlyne $(1958,1963,1974)$ in his motivational model of New Experimental Aesthetic, which emphasizes the aesthetic effects of isolated features or dimensions of stimuli. The model posits that the traceable information is based on semantic (characteristics of an external object), expressive (psychological processes within the artist), cultural (social norms), and syntactic (characteristics of other elements of the object) information. Although there is some overlap between the four types of information, they mostly emit independent information. This occurs due to competition among them for the limited capacity of the channel linking them with the work. For example, more information content from one will generally mean less content from the others. Thus, collative properties defined by Berlyne (1974) as structural properties, such as variations along simplicity-complexity, familiaritynovelty, certainty-uncertainty - present in the stimulus may produce hedonic value and changes of arousal. Berlyne, Ogilvie and Parham (1968) carried out a study in which the participants were asked to rate the complexity, pleasingness and interestingness levels of a series of cards. The results showed that judged complexity was a major determinant of judged interestingness and judged pleasingness.

Studies have been carried out involving different modalities of artistic expressions, such as music (Firmino \& Bueno, 2008), paintings (Cupchick, Vartanian, Craqley, \& Mikulis, 2009; Nather, Bueno, Bigand, \& Droit-Volet, 2011; Verhavert, Wagemans, \& Augustin, 2018), and sculptures (Modica et al., 2016). Regarding visual artworks, some investigations considered different procedures to identify how people judge visual artworks have been carried out (Cupchick \& Gignac, 2007; Cupchick \& Shereck, 1998; Friedenberg, 2018; Marin \& Leder, 2016; Silva et al., 2018). Most of these studies evaluation used scales to rate the artworks. For example, Cupchik and Shereck (1998) asked subjects to rate sculptures on Semantic 7-point-Likert scales in terms of emotional and intellectual items. However, this study involved the evaluation of artworks such as sculptures using only the visual sense, i.e., the subjects were required to observe the artworks only and were not allowed to interact by touching them. Several studies have pointed out the importance of touch for the aesthetic experience, mainly for the appreciation of sculptures (Candlin, 2017; Classen, 2005, 2012; Irvin, 2013; Kenaan, 2016).

The Neo-Concrete movement, which arose in Brazil around 1957 was an artistic movement marked by the challenge of reducing the distances between the creation and reception of art. The emphasis was on establishing a transition from mere contemplation to active participation in artworks (Brito, 1999; Valdivieso \& Freitas, 2012). Lygia Clark (19201988), an outstanding artist in this movement (see Butler \& Pérez-Oramas, 2014 for the international impact of her work), started working in the late 1950s, producing monochromatic paintings and reliefs. She then followed a sculpture trend that argued that objects would only have meaning to the participant if he/she manipulated the artwork (being no longer a simple spectator), which would provide them with a multisensory experience (Brett, 1994). Thus, in 1959, Lygia created the Bichos (animals), a series of around 70 sculptures in total (Butler \& Pérez-Oramas, 2014). They were presented to the public in 1960. Bichos is the name the artist gave to geometric plates of anodized aluminum, joined by hinges that allow displacement in space by creating different forms triggered by the action of the spectator-participant (Carvalho, 2011). Their parts are functionally associated with each other and their movements are interrelated (Brett, 1994). According to Scovino (2003), the Bichos series increased participation and sensorial perception. From this perspective, in which the act assumes the value of artwork, the interaction with the artistic object can exert influence on the aesthetic experience. (Nadal, Gallardo, \& Marty, 2018).

This study examines how different features of sculptures modified from originals of the Bichos series by Lygia Clark, influence their artistic appreciation. Perceptual and emotional collative properties of artworks (Complexity, Regularity, Amount of pieces, Interest and Pleasure) were assessed using Semantic Differential Scales (7-pointLikert scales), which are important fundamental perceptual schemes that for understanding artistic appreciation.

An artwork presented within a context of different levels of information can be differently evaluated by participants (Berlyne, 1974). Thus, one sculpture modified from the originals of the Bichos series by Lygia Clark was exposed in two different ways: first, among artworks presenting different structural standards (number of flat pieces, size of sculpture and different sequence of flat pieces); and second, it was presented among artworks with the same structural standard, but with different numbers of only one of their elements: the flat parts. Studies have found that the context in which an artwork is exposed influences the way it is appreciated as well as the exploratory behavior (Cupchik \& Shereck, 1998; Gerger \& Leder, 2015). Since the artworks were exposed simultaneously and participants were allowed to explore each one of them for as long as they wanted, we also registered the exploration time of each piece of art.

\section{Method}

\section{Participants}

A sample of 13 graduate psychobiology students (4 women and 9 men; age range 25-33 years; mean age 
$27.84 \pm 2.33$ ) from the University of São Paulo at Ribeirão Preto were randomly selected and invited to participate in the study. We applied a questionnaire to the participants in order to verify their knowledge about artistic activities, which could interfere in their perception on artworks. No participant reported previous systematic and formal training.

\section{Instruments}

Stimuli. We selected the sculpture entitled Caranguejo, versão 01 (Crab, version 01) from the Bichos series, by Lygia Clark. The selection was based on the objectives of the study; therefore it was possible to include parts and modify their structures. Five modified sculptures of the original work mentioned (Figure 1) served as stimuli. Three stimuli consisted of flat parts of cardboard paper. Each piece was shaped as a scalene triangle, with dimensions of $26 \times 17 \times$ $14.5 \mathrm{~cm}$. One side of each flat piece was connected to another flat piece with scotch tape, which allowed participants to move them in many configurations. Three stimuli consisted of different numbers of flat parts with the same structure: 6 , 8 and 10, and were called stimuli B6, B8 (stimulus which maintained the same number of pieces and structure of originals artwork) and B10, respectively. The two remaining stimuli exhibited a different structural standard (number, size and different sequence of flat pieces). Thus, one of them was formed of flat pieces with the geometric shape of an isosceles triangle, with dimensions of $17 \times 12 \times 12 \mathrm{~cm}$ and was called stimulus $\mathrm{Ba}$. The other stimulus was formed of flat pieces with the geometric shape of a scalene triangle, with dimensions of $25 \times 23 \times 10 \mathrm{~cm}$ and was called stimulus $\mathrm{Bb}$.

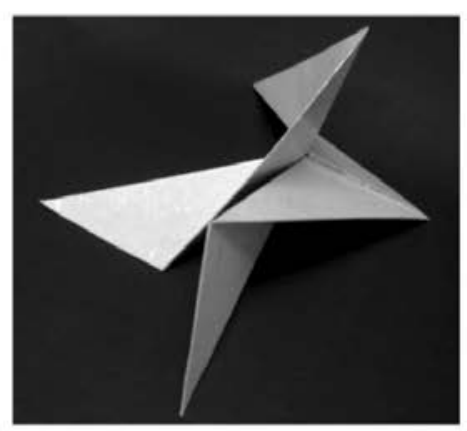

B6 Stimulus

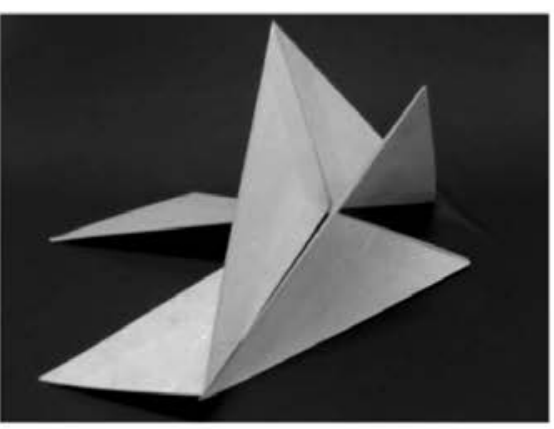

B8 Stimulus

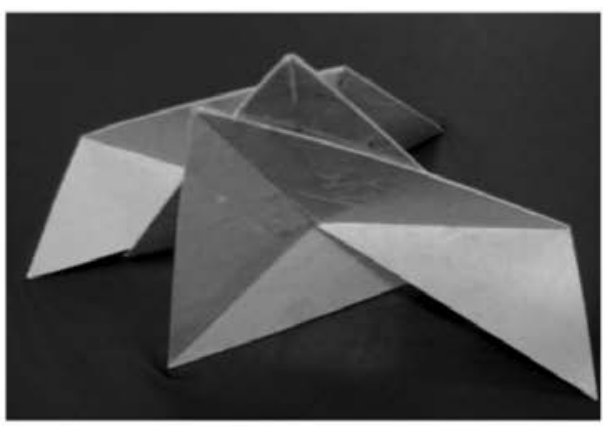

B।0 Stimulus

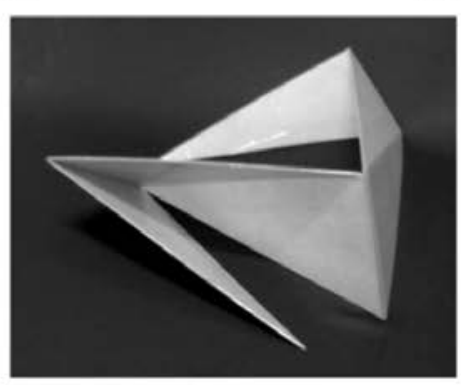

Ba Stimulus

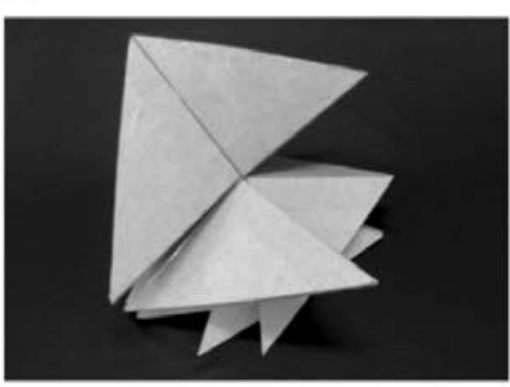

Bb Stimulus

Figure 1. The five altered sculpture from originals of the series Bichos by Lygia Clark (1960). Stimuli presenting different numbers of flat parts: B6, B8 and B10. Stimuli presenting different structural standard (number, size and different sequence of flat pieces): $\mathrm{Ba}$ and $\mathrm{Bb}$.

Semantic Differential Scales. The participants indicated their perceptions using a 7-point Likert scale to assess five stimuli: (1) Simple-Complex, (2) Irregular-Regular, (3) Few pieces-Many pieces, (4) Interesting-Uninteresting and (5) Pleasing-Displeasing. The scales were based on the collative properties of stimuli proposed by Berlyne (1973) to measure reactions of viewers to various aesthetic stimuli. The authors chose these scales because they had been extensively used in previous studies, therefore their psychometric properties were well understood. The first three scales aimed at judging stimulus characteristics, whereas the last two required ratings of positive and negative hedonic tone (Figure 2). 


\begin{tabular}{|c|c|c|c|c|c|c|c|c|}
\hline & & & & 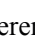 & Sca & & & \\
\hline & $1 \mathrm{Pl}$ & $\mathrm{ra}$ & & com & ity & e ol & & \\
\hline Simple & 1 & 2 & 3 & 4 & 5 & 6 & 7 & Complex \\
\hline & & se 1 & $\mathrm{ou}$ & res & ity & e ol & & \\
\hline Regular & 1 & 2 & 3 & 4 & 5 & 6 & 7 & Irregular \\
\hline & Plea & ate & Ie & our & pie & f th & jec & \\
\hline Few pieces & 1 & 2 & 3 & 4 & 5 & 6 & 7 & Many pieces \\
\hline & Plea & ate & leg & $f$ in & tin & se $b$ & jjec & \\
\hline Interesting & 1 & 2 & 3 & 4 & 5 & 6 & 7 & Uninteresting \\
\hline $5 \mathrm{Ple}$ & ate th & egr & & $\operatorname{lgn}$ & $\mathrm{tyc}$ & $\mathrm{mot}$ & al ex & erience: \\
\hline Pleasing & 1 & 2 & 3 & 4 & 5 & 6 & 7 & Displeasing \\
\hline
\end{tabular}

Figure 2. Five Semantic Differential Scales (7-point Likert scale): Simple-Complex, Regular-Irregular, Few pieces-Many pieces, Interesting-Uninteresting, Pleasing-Displeasing.

\section{Procedure}

Data collection. We tested the participants individually. Data collection was performed during daylight in an isolated, sound-proof room at the Center for Experimental Aesthetics of the University of São Paulo, with lights off during the day (indirect sunlight). The room contained a table where the stimuli were arranged and a chair for the participant. The procedure involved two phases. In Phase 1, the experimenter determined how artworks presenting different structural standards (number, size and different sequences of flat pieces) were appraised by the participants when exposed together. Thus, $\mathrm{B} 8, \mathrm{Ba}$ and $\mathrm{Bb}$ stimuli were presented to the participant, who was instructed to touch and manipulate one stimulus at a time for as long as he/she wanted. The participants were not blindfolded; therefore, they could see the stimuli as they touched and manipulated. The duration of manipulation was recorded with a stop-watch by the experimenter. After manipulating the three stimuli, the participant was then instructed to rate each stimulus along each locution of the Semantic Differential Scale, filling the form presented by the experimenter. During the filling of the form the stimuli remained exposed; although there was no explicit instruction, no participant touched or manipulated them. After that, the phase 2 was immediately initiated.

In Phase 2, the experimenter examined how artworks presenting the same structural standard, but with different numbers of flat parts, were evaluated by the participants when exposed together. Thus, stimuli B6, B8 and B10, which contained different numbers of flat parts and the same structure, were presented to the same participants following the same procedure as in Phase 1. The order of exposition of the stimuli on the table was changed in each phase for all participants. However, the B8 stimulus was exposed in the two phases of comparisons to verify its appreciation within different contexts. Therefore, the stimulus B8 was selected to be exposed twice as it maintained the same structure and the same number of flat parts as the original artwork. After the data collection, the participants were asked if they have had any previous contact with the artworks used in the study. All participants answered that they have never had contact with the Lygia Clark artworks.

Data analysis. We applied the Friedman test to assess differences among the ratings at each stimulus for each locution Semantic Differential Scale; and we used the Wilcoxon test for post hoc comparisons. We used ANOVA to test differences in touching time for each stimulus. And we used SPSS software, version 18.0 (SPSS Inc., Chicago, IL) to perform all procedures with level of significance set at .005 .

\section{Ethical Considerations}

The participants received explanations about the significance of the study, procedures, and study implications. All participants signed a Declaration of Informed Consent in compliance with the ethical procedures required to perform the study, which was approved by the Ethics Committee of the University of São Paulo, School of Philosophy, Sciences, and Letters of Ribeirão Preto (CAAE No.: 41620515.6.0000.5407).

\section{Results}

Comparisons of Stimuli Presenting Different Structural Standards (number, size and different sequences of flat pieces) - Ba, Bb and B8 stimuli

Comparisons of the $\mathrm{Ba}, \mathrm{Bb}$ and $\mathrm{B} 8$ stimuli indicated that stimulus B8 had the highest level of Complexity as 
compared to $\mathrm{Ba}$ and $\mathrm{Bb}(p=.008, p=.002$, respectively). The same differences among stimuli ratings were observed for Irregularity level ( $p=.001, p=.007$, respectively). Also, stimulus $\mathrm{Bb}$ had a higher level of Complexity and larger Amount of pieces as compared to stimulus $\mathrm{Ba}$ ( $p=.005, p=.010$, respectively). And a lower Amount of pieces and lesser Interestingness were attributed to stimulus Ba compared to B8 ( $p=.006, p=.024$, respectively). For Pleasingness level there no was interaction among stimuli. Table 1 shows the means and standard deviations of the participants' judgments on each 7-point scale in response to stimuli $\mathrm{Ba}, \mathrm{Bb}$ and $\mathrm{B} 8$.

Table 1

Mean \pm Standard Deviation of the Judgments of Participants on Each 7-Point Semantic Differential Rating Scale of the Stimuli that Presented Different Structural Standard

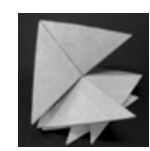

Bb

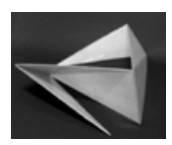

Ba

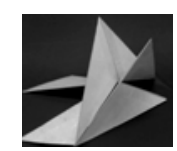

B8

\begin{tabular}{lccc} 
Complex & $5.23 \pm 1.4^{\mathrm{ab}}$ & $3.31 \pm 1,7^{\mathrm{ac}}$ & $6.23 \pm 0.8^{\mathrm{bc}}$ \\
Irregular & $3.23 \pm 1.9^{\mathrm{a}}$ & $3.38 \pm 1.7^{\mathrm{b}}$ & $5.85 \pm 1,4^{\mathrm{ab}}$ \\
Pieces & $3.92 \pm 1,3^{\mathrm{a}}$ & $2.92 \pm 1,3^{\mathrm{ab}}$ & $4.00 \pm 1,2^{\mathrm{b}}$ \\
Interesting & $2.46 \pm 1,6$ & $3,31 \pm 1,6^{\mathrm{a}}$ & $1.92 \pm 1,1^{\mathrm{a}}$ \\
Pleasing & $2.62 \pm 1,3$ & $3.00 \pm 1,5$ & $2.38 \pm 1,3$ \\
\hline
\end{tabular}

Note. ${ }^{\mathrm{a}, \mathrm{b}, \mathrm{c}}=$ Significant difference among stimuli for each rating scale (Complexity, Regularity, Quantity of pieces, Interest and Pleasure). Significant difference $(p<0.05)$.

\section{Comparisons of Stimuli that Presented the Same Structural Standard and Different Numbers of Flat Parts - B6, B8 and B10 stimuli}

Comparisons among stimuli B6, B8 and B10 showed lower Complexity level attributed to stimulus B6 as compared to stimuli B8 and B10 ( $p=.003, p=.002$, respectively), and the same was observed for Irregularity level ( $p=.015, p=.008$, respectively). Also, a larger Amount of pieces was attributed to stimulus B10 than to stimulus B6 $(p=.027)$. Lower Pleasingness was attributed to stimulus B10 as compared to stimuli B6 and B8 ( $p=.026, p=.009$, respectively). For Interestingness level there was no interaction among stimuli. Table 2 shows the means and standard deviations of the judgments of participants on each 7-point scale in response to stimuli B6, B8 and B10.
Table 2

Mean \pm Standard Deviation of the Judgments of Participants on Each 7-Point Semantic Differential Rating Scale of the Stimuli that Presented the Same Structural Standard and Different Numbers of Flat Parts

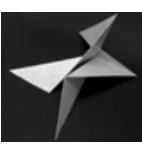

B6

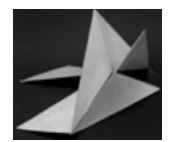

B8

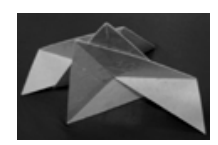

B10

\begin{tabular}{|c|c|c|c|}
\hline Complex & $3.54 \pm 1,3^{\mathrm{ab}}$ & $6.23 \pm 0,8^{\mathbf{b}}$ & $6.31 \pm 0,6^{\mathbf{a}}$ \\
\hline Irregular & $4.08 \pm 1,5^{\mathrm{ab}}$ & $5.85 \pm 1,4^{\mathbf{b}}$ & $5.62 \pm 1,6^{\mathrm{a}}$ \\
\hline Pieces & $3.31 \pm 1,3^{\mathrm{a}}$ & $4.00 \pm 1,2$ & $4.54 \pm 1,3^{\mathrm{a}}$ \\
\hline Interesting & $3.46 \pm 1,5$ & $1.92 \pm 1,1$ & $2.85 \pm 1,8$ \\
\hline Pleasing & $2.62 \pm 1,1^{\mathrm{a}}$ & $2.38 \pm 1,3^{\mathbf{b}}$ & $4.00 \pm 1,9^{\mathrm{ab}}$ \\
\hline
\end{tabular}

\section{Comparison of Touching Time among Stimuli}

The participants tended to spend more time inspecting more complex sculptures. Among $\mathrm{Ba}, \mathrm{Bb}$ and $\mathrm{B} 8$, which showed different structural standards (number, size and different sequences of flat pieces), stimulus B8 $(98.08 \pm 33)$ elicited longer touching time than stimulus $\mathrm{Ba}(61.38 \pm 27.2)$ and $\mathrm{Bb}(86.69 \pm 44.8)$. There was touching time interaction between $\mathrm{Ba}$ and $\mathrm{B} 8(p=.035)$.

Stimuli B6, B8 and B10 showed the same structural standard and different numbers of flat parts. B8 $(76,85 \pm 40)$ elicited a longer mean duration of touching than B6 $(61,15 \pm 26,5)$ and $B 10(65,15 \pm 27,9)$. We observed no interaction among these stimuli. Such findings indicate that the B8 stimulus presented greater touching time when explored among stimuli that had different structural patterns (number, size and different sequences of flat pieces) than among stimuli that had the same structural pattern and different numbers of flat parts (B6, B8 and B10).

\section{Discussion}

Specific features of objects affect the way they are perceived. This study focused on the judgment of modified sculptures of the Bichos series by Lygia Clark, which were touched and manipulated by the participants. Our results showed that the features of stimuli such as Complexity, Irregularity and Amount of pieces were accompanied by differences in hedonic values, indicated by the level of Interest or Pleasure of the participants. We observed that 
the stimuli judged as having a large Amount of pieces were also evaluated as presenting high levels of Complexity and Irregularity. In addition, the stimuli evaluated as displaying high levels of Complexity and Irregularity were considered more interesting, although less pleasing.

These findings are in accordance with the collativemotivation model of Berlyne $(1958,1963,1974)$. Thus, it is possible to consider that the amount of pieces of an artwork can be related to its information content. A large amount of pieces would be associated with high informational content, which would be perceived as a rich source of information and therefore the artwork would arouse more interest $(\mathrm{B} 8>\mathrm{Bb})$. Such results confirmed by our findings, which showed that the artworks considered more complex, irregular and interesting, and with a large amount of pieces, were manipulated longer than the artworks considered less complex, irregular and less interesting, and with a smaller number of pieces. The exploratory behavior of the participants can be considered to be an indicator of the level of interest for an artwork. Berlyne (1958) verified the time that the participants spent looking at figures presenting different forms of complexity (irregularity of arrangement, amount of material, heterogeneity of elements, irregularity of shape, incongruity and incongruous juxtaposition) and observed that the participants tended to spend more time on the inspection of more complex stimuli, probably due to a preference for looking at a rich source of information.

The low-level of pleasingness of artwork considered complex $(\mathrm{B} 10<\mathrm{B} 6$ and $\mathrm{B} 10<\mathrm{B} 8)$ may be precisely related to the excess of information indicated by the number of pieces perceived $(\mathrm{B} 10>\mathrm{B} 6)$. A possible explanation for these findings might be that the larger the amount of elements present in an object, the more complex and irregular it will look, and thus more interesting. However, there is an optimal level of information related to the hedonistic value of the stimulus, and that above this level the stimulus tends to be considered less pleasing (Berlyne, 1958, 1963). Neuroscience aesthetic studies have shown a relationship between difficulty of the exploration task and hedonic value in the appreciation of a piece of art (Chatterjee \& Vartanian, 2016). Several studies have pointed out that neural regions related to the interpretation of information (Pelowski, Markey, Forster, Gerger, \& Leder, 2017), higherorder semantic analysis (Clarke \& Tyler, 2014; Pearce et al., 2016) and reward system (Kampe, Frith, Dolan, \& Frith, 2001) are activated during aesthetic appraisal. In addition, Gerger and Leder (2015) suggested that positive aesthetic experiences are driven by easy processing. They conducted a study in which participants were asked to evaluate paintings accompanied by three different title types: self-generated titles by the authors, which are related to the content of the artworks; or titles that did not correspond to the content of the artwork; or "untitled". The results showed that liking ratings were higher for titles generated by the authors (related to the content of the artworks) and for "untitled" than for titles generated that did not correspond to the artwork. According to the authors, in the condition of self-generated titles by them, relating to the content of artworks, the processing was facilitated, contributing to higher aesthetic ratings associated with positive emotions, therefore making the appreciation of paintings more pleasurable. This result is in accordance with our assumption that the difficulty in processing the artwork information content renders it more complex, which makes the appraisal of the artwork less pleasurable.

In addition, Berlyne (1963) found that the longer exposure time of pairs of images with different levels of complexity decreased the probability that the more complex figure would be chosen for a better inspection. According to Berlyne, this is compatible with the view that there is a preferred optimum of information content to which subjects seek to expose themselves. Thus, there would be a relationship between time of exposure to the object and an optimal limit of information content in order for the object to be perceived as pleasurable. However, in contrast to the study of Berlyne, our findings show that, although an artwork is considered displeasing when more complex, this does not seem to affect the level of interest aroused by it. In our study, artworks considered complex and with a highlevel of Interest were manipulated for a longer time, even if evaluated with a high level of Displeasingness. It is important to note that in this study, although the participants could set the time of exposure to the stimuli, the proposed task was different from that required by Berlyne, which consisted just of the visual inspection of images, whereas in our study the participants were asked to touch and manipulate artwork pieces; moreover, looking at the stimuli. The exploratory behavior is influenced by the kind of interaction, which involves the multisensory integration (Dumas, Holtzer, \& Mahoney, 2016; Tang, Wu, \& Shen, 2016) and haptic perception (Klatzky \& Lederman, 1995). The present study employs not only visual, but also tactile stimuli, which are integrated into the manipulation of the artwork.

It is important to point out that, although the stimuli were presented under different conditions - diverse structural standards (number of flat pieces, size of the pieces and different sequences of flat pieces) and same structural standards with different numbers of flat parts - the participants judged the stimuli in a similar way in both cases, i.e., the stimuli considered to involve more pieces were judged to have a higher level of complexity and irregularity than the stimuli considered to involve few pieces. Since the ability to process information content influences the evaluation of artwork, it is possible to infer that our results may be related to a limited capacity of understanding the stimuli and with difficulty in processing information. In this respect, evidence suggests that whereas the preference level of naïve subjects is strongly influenced by the level of abstraction and surface features, participants with formal training in the arts are more sensitive to the underlying structural features of artworks (Chatterjee \& Vartanian, 2016; Koide, Kubo, Nishida, Shibata, \& Ikeda, 2015; Leder, Gerger, Brieber, \& Schwarz, 2014; Mullennix \& Robinet, 2018; Pelowski, Markey, Lauring, \& Leder, 2016). Thus, our study indicates that the skill to pay attention and understand profound aspects of artworks might influence 
the way they are perceived. In addition, our results indicate that some specific features of an object may influence the way it is perceived independently of the context in which it is exposed.

At the same time, although different contexts do not appear to affect the way in which an artwork is perceived, they seem to influence the time of its exploration. In our study, the B8 stimulus, considered to have a high level of complexity, irregularity and interest, was manipulated for a longer time than the other stimuli in the two different conditions in which it was exposed. However, it is important to emphasize the significant difference in touching time between the $\mathrm{B} 8$ and $\mathrm{Ba}$ stimuli in the first condition, in which stimuli had different structural standards, but not for stimuli in the second condition, in which they had the same structural standard and different numbers of flat parts. A possible explanation is that in the second condition the stimuli presented the same structural arrangement, varying only in the amount of pieces, and also that the B8 stimulus was presented in the second time. Thus, this difference in novelty could be responsible for our results.

This study investigated how features highlighted in artworks are perceived. Based on what we discussed, the following possible explanations can be drawn from the results. First, stimulus features such as Complexity, Irregularity and Amount of pieces influence its hedonic value, i.e., the level of interest and pleasure. Second, touching sculptures is a particular way of exploration, suggesting that the kind of interaction with the artwork, either visual or tactile, influences the way it is perceived. In this study, the participants not only observed, but also touched and manipulated the artworks. Third, the capacity to understand the artwork and thus to better process its information content may influence its aesthetic appraisal. Finally, specific features of an artwork may affect the way it is perceived independently of the context in which it is exposed. However, such context may affect the exploration behavior. Such findings extend the understanding about the influence of features on aesthetic experience, and, especially how the artist's concepts and messages may be understood and how they can deepen the aesthetic engagement of an observer with an artwork. The use of non-original artworks and the absence of determination of the time of exploitation of them may have contributed as limiting factors to the study. In addition, the small sample and the fact that all participants were students of a single course (psychobiology) may also be a limitation; a study with a larger and more diversified sample should contribute to increase the generality of the results found. Moreover, experimental data comparing the judgment of artworks when explored in different conditions, such as just by naked eye; only by manipulation; and also combining naked eye with manipulation could increase the generality of our statements. Thus, future studies focused on the evaluation of original artwork and the establishment of different fixed times for the exhibition of the work would contribute to a better understanding of artistic appreciation.

\section{References}

Aksentijevic, A., \& Gibson, K. (2012). Complexity equals change. Cognitive Systems Research, 15-16, 1-16. doi:10.1016/j.cogsys.2011.01.002

Berlyne, D. E. (1958). The influence of complexity and novelty in visual figures on orienting responses. Journal of Experimental Psychology, 55(3), 289-296. doi: $10.1037 / \mathrm{h} 0043555$

Berlyne, D. E. (1963). Complexity and incongruity variables as determinants of exploratory choice and evaluative ratings. Canadian Journal of Psychology, 17(3), 274-290. doi: $10.1037 / \mathrm{h} 0092883$

Berlyne, D. E. (1973). Interrelations of verbal and nonverbal measures used in experimental aesthetics. Scandinavian Journal of Psychology, 14(1), 177-184. doi:10.1111/j.1467-9450.1973.tb00107.x

Berlyne, D. E. (1974). The new experimental aesthetics. In D. E. Berlyne (Ed.), Studies in the new experimental aesthetics (pp. 1-25). Toronto, Canada: University of Toronto.

Berlyne, D. E., Ogilvie, J. C., \& Parham, L. C. (1968). The dimensionality of visual complexity, interestingness, and pleasingness. Canadian Journal of Psychology, 22(5), 376-387. doi:10.1037/h0082777

Brett, G. (1994). Lygia Clark: In search of the body. Art in America, 82(7), 56-63. Retrieved from https://www.csus. edu/indiv/o/obriene/art111/readings/InSearchoftheBody.pdf

Brito, R. (1999). Neoconcretismo: Vértice e ruptura do projeto construtivo brasileiro [Neoconcretism: Vertex and rupture of the Brazilian construction project]. Rio de Janeiro, RJ: FUNARTE/Instituto Nacional de Artes Plásticas.

Bueno, J. L. O., \& Ramos, D. (2007). Musical mode and estimation of time. Perceptual and Motor Skills, 105(3 Pt. 2), 1087-1092. doi:10.2466/pms.105.4.1087-1092

Butler, C. H., \& Pérez-Oramas, L. (2014). Lygia Clark: The abandonment of art, 1948-1988. New York, NY: The Museum of Modern Art.

Calvo, M. G., Gutiérrez-García, A., \& Del Líbano, M. (2015). Sensitivity to emotional scene content outside the focus of attention. Acta Psychologica, 161, 36-44. doi:10.1016/j.actpsy.2015.08.002

Candlin, F. (2017). Rehabilitating unauthorised touch or why museum visitors touch the exhibits. Senses and Society, 12(3), 251-266. doi:10.1080/17458927.2017.1367485

Carvalho, D. H. B. (2011). O corpo na poética de Lygia Clark e a participação do espectador [The body in the poetics of Lygia Clark and the spectator participation]. MoringaArtes do Espetáculo, 2(2), 131-142. Retrieved from http://www.periodicos.ufpb.br/ojs/index.php/moringa/ article/view/11756 
Chatterjee, A., \& Vartanian, O. (2016). Neuroscience of aesthetics. Annals of the New York Academy of Sciences, 1369(1), 172-194. doi:10.1111/nyas.13035

Clarke, A., \& Tyler, L. K. (2014). Object-specific semantic coding in human perirhinal cortex. Journal of Neuroscience, 34(14), 4766-4775. doi:10.1523/ JNEUROSCI.2828-13.2014

Classen, C. (2005). Touch in the museum. In C. Classen (Ed.), The book of touch (pp. 275-288). Oxford, United Kingdom: Berg.

Classen, C. (2012). Tactile arts. In C. Classen (Ed.), The deepest sense: A cultural history of touch (pp. 123-146). Urbana, IL: University of Illinois Press.

Crozier, W. R. (2018). Gerald C. Cupchik. The aesthetics of emotion: Up the down staircase of the mindbody. Empirical Studies of the Arts, 36(1), 114-121. doi:10.1177/0276237417723263

Cupchik, G. C., \& Gignac, A. (2007). Layering in art and in aesthetic experience. Visual Arts Research, 33(1), 56-71. Retrieved from http://www.jstor.org/stable/20715434

Cupchik, G. C., Leonard, G., Axelrad, E., \& Kalin, J. D. (1998). The landscape of emotion in literary encounters. Cognition and Emotion, 12(6), 825-847. doi:10.1080/026999398379457

Cupchik, G. C., \& Shereck, L. (1998). Generating and receiving contextualized interpretations of figurative sculptures. Empirical Studies of the Arts, 16(2), 179-191. doi:10.2190/DR21-Q20D-XNED-VXP8

Cupchik, G. C., Vartanian, O., Crawley, A., \& Mikulis, D. J. (2009). Viewing artworks: Contributions of cognitive control and perceptual facilitation to aesthetic experience. Brain and Cognition, 70(1), 84-91. doi:10.1016/j. bandc.2009.01.003

Dumas, K., Holtzer, R., \& Mahoney, J. R. (2016). Visualsomatosensory integration in older adults: Links to sensory functioning. Multisensory Research, 29(4-5), 397-420. doi:10.1163/22134808-00002521

Firmino, E. A., \& Bueno, J. L. O. (2008). Tonal modulation and subjective time. Journal of New Music Research, 37(4), 275-297. doi:10.1080/09298210802711652

Friedenberg, J. (2018). Geometric regularity, symmetry and the perceived beauty of simple shapes. Empirical Studies of the Arts, 36(1), 71-89. doi:10.1177/0276237417695454

Gerger, G., \& Leder, H. (2015). Titles change the esthetic appreciations of paintings. Frontiers in Human Neuroscience, 9, 464. doi:10.3389/fnhum.2015.00464

Irvin, S. (2013). Sculpture. In B. Gaut \& D. M. Lopes (Eds.), The Routledge companion to aesthetics (pp. 606-615). London, United Kingdom: Routledge/Taylor \& Francis.
Kampe, K. K. W., Frith, C. D., Dolan, R. J., \& Frith, U. (2001). Reward value of attractiveness and gaze. Nature, 413(6856), 589. doi:10.1038/35098149

Kenaan, H. (2016). Touching sculpture. In P. Dent (Ed.), Sculpture and touch (pp. 45-60). London, United Kingdom: Routledge/Taylor \& Francis.

Klatzky, R. L., \& Lederman, S. J. (1995). Identifying objects from a haptic glance. Perception \& Psychophysics, 57(8), 1111-1123. doi:10.3758/BF03208368

Koide, N., Kubo, T., Nishida, S., Shibata, T., \& Ikeda, K. (2015). Art expertise reduces influence of visual salience on fixation in viewing abstract-paintings. PLoS One, 10(2), e0117696. doi:10.1371/journal.pone.0117696

Leder, H., Belke, B., Oeberst, A., \& Augustin, D. (2004). A model of aesthetics appreciation and aesthetic judgments. British Journal of Psychology, 95(Pt. 4), 489-508. doi:10.1348/0007126042369811

Leder, H., Gerger, G., Brieber, D., \& Schwarz, N. (2014). What makes an art expert? Emotion and evaluation in art appreciation. Cognition and Emotion, 28(6), 1137-1147. doi:10.1080/02699931.2013.870132

Marin, M. M., \& Leder, H. (2016). Effects of presentation duration on measures of complexity in affective environmental scenes and representational paintings. Acta Psychologica, 163, 38-58. doi:10.1016/j. actpsy.2015.10.002

Marin, M. M., \& Leder, H. (2018). Exploring aesthetic experiences of females: Affect-related traits predict complexity and arousal responses to music and affective pictures. Personality and Individual Differences, 125, 80-90. doi:10.1016/j.paid.2017.12.027

Modica, E., Rossi, D., Cherubino, P., Trettel, A., Picconi, D., Maglione, A. G., ... Babiloni, F. (2016). Cerebral perception and appreciation of real paintings and sculptures by neuroelectric imaging. International Journal of Bioelectromagnetism, 18(2), 46-52. Retrieved from http://www.ijbem.org/

Mullennix, J. W., \& Robinet, J. (2018). Art expertise and the processing of titled abstract art. Perception, 47(4), 359-378. doi:10.1177/0301006617752314

Nadal, M., Gallardo, V., \& Marty, G. (2018). Commentary: But is it really art? The classification of images as "art"/"not art" and correlation with appraisal and viewer interpersonal differences. Frontiers in Psychology, 8, 2328. doi:10.3389/fpsyg.2017.02328

Nather, F. C., Bueno, J. L. O., Bigand, E., \& Droit-Volet, S. (2011). Times changes with the embodiment of another's body posture. PLoS One, 6(5), e19818. doi:10.1371/ journal.pone. 0019818 
Pearce, M. T., Zaidel, D. W., Vartanian, O., Skov, M., Leder, H., Chatterjee, A., \& Nadal, M. (2016). Neuroaesthetics: The cognitive neuroscience of aesthetic experience. Perspectives on Psychological Science, 11(2), 265-279. doi:10.1177/1745691615621274

Pelowski, M., Markey, P. S., Forster, M., Gerger, G., \& Leder, H. (2017). Move me, astonish me... delight my eyes and brain: The Vienna Integrated Model of top-down and bottom-up processes in Art Perception (VIMAP) and corresponding affective, evaluative, and neurophysiological correlates. Physics of Life Reviews, 21, 80-125. doi:10.1016/j.plrev.2017.02.003

Pelowski, M., Markey, P. S., Lauring, J. O., \& Leder, H. (2016). Visualizing the impact of art: An update and comparison of current psychological models of art experience. Frontiers in Human Neuroscience, 10, 160. doi:10.3389/fnhum.2016.00160

Scovino, F. (2003). A vontade poética no diálogo com os Bichos: O ponto de chegada de uma arte participativa no Brasil [Poetic desire to dialogue with animals: Destination of a participatory art in Brazil]. Arte \& Ensaios, 10, 26-35. Retrieved from https://www.ppgav. eba.ufrj.br/wp-content/uploads/2013/11/A-VontadePo\%C3\%A9tica-no-Di\%C3\%A1 logo-com-os-Bichoso-ponto-de-chegada-de-uma-arte-participativa-noBrasilFelipe-Scovino.pdf

Silvia, P. J., Christensen, A. P., Cotter, K. N., Jackson, T. A., Galyean, C. B., McCroskey, T. J., \& Rasheed, A. Z. (2018). Do people have a thing for bling? Examining aesthetic preferences for shiny objects. Empirical Studies of the Arts, 36(1), 101-113. doi:10.1177/0276237417712808

Tang, X., Wu, J., \& Shen, Y. (2016). The interactions of multisensory integration with endogenous and exogenous attention. Neuroscience \& Biobehavioral Reviews, 61, 208-224. doi:10.1016/j.neubiorev.2015.11.002

Tinio, P. P. L. (2013). From artistic creation to aesthetic reception: The mirror model of art. Psychology of Aesthetics, Creativity, and the Arts, 7(3), 265-275. doi:10.1037/a0030872

Valdivieso, T. V., \& Freitas, A. (2012). Do objetual ao coletivo: Lygia Clark e a participação do espectador nos anos 1960 [From the object to the collective: Lygia Clark and the participation of the espectator in the 1960s]. $O$ Mosaico, (8), 30-42. Retrieved from http://periodicos. unespar.edu.br/index.php/mosaico/article/view/43/pdf

Verhavert, S., Wagemans, J., \& Augustin, M. D. (2018). Beauty in the blink of an eye: The time course of aesthetic experiences. British Journal of Psychology, 109(1), 63-84. doi:10.1111/bjop. 12258
Zhang, J., Yang, T., Bao, Y., Li, H., Pöppel, E., \& Silveira, S. (2018). Sadness and happiness are amplified in solitary listening to music. Cognitive Processing, 19(1), 133-139. doi:10.1007/s10339-017-0832-7

José Lino Oliveira Bueno is a Professor of the Faculdade de Filosofia, Ciências e Letras at Ribeirão Preto of the Universidade de São Paulo, Ribeirão Preto-SP, Brazil.

Márcia Regina Motta is a Ph.D. student of the Faculdade de Filosofia, Ciências e Letras at Ribeirão Preto of the Universidade de São Paulo, Ribeirão Preto-SP, Brazil.

Vitor Tumas is a Professor of the Faculdade de Medicina at Ribeirão Preto of the Universidade de São Paulo, Ribeirão Preto-SP, Brazil.

\section{Authors' Contribution:}

The authors Márcia Regina Motta and José Lino Oliveira Bueno made substantial contributions to the conception and design of this study, to the analysis and interpretation of data and to the review and approval of the manuscript of the final version. Márcia Regina Motta also collected the data and wrote the first version of the article. Vitor Tumas made substantial contributions to the conception and design of this study and to the revision of the final version of the manuscript. All the authors assume public responsability for content of the manuscript.

Received: Apr. 18, 2018

1st Revision: Jul. 24, 2018

Approved: Oct. 10, 2018

\section{How to cite this article:}

Bueno, J. L. O., Motta, M. R, \& Tumas, V. (2020). Effects of touching sculptures on the artistic appreciation of collative emotional/perceptual properties. Paidéia (Ribeirão Preto), 30, e3021.doi:http://dx.doi.org/10.1590/1982-4327e3021 